Portland State University

PDXScholar

$5-31-1977$

\title{
Effects of Types 1 and 2 Herpes Simplex Viruses on Several Fish Tissue Culture Systems
}

Raymond Charles Harry

Portland State University

Follow this and additional works at: https://pdxscholar.library.pdx.edu/open_access_etds

Part of the Biology Commons, and the Other Immunology and Infectious Disease Commons Let us know how access to this document benefits you.

\section{Recommended Citation}

Harry, Raymond Charles, "Effects of Types 1 and 2 Herpes Simplex Viruses on Several Fish Tissue Culture Systems" (1977). Dissertations and Theses. Paper 2606.

https://doi.org/10.15760/etd.2602

This Thesis is brought to you for free and open access. It has been accepted for inclusion in Dissertations and Theses by an authorized administrator of PDXScholar. Please contact us if we can make this document more accessible: pdxscholar@pdx.edu. 
AN ABSTRACT OF THE THESIS OF Raymond Charles Harry for the Master of Science in Biology presented 31 May 1977.

Title: Effects of Types 1 and 2 Herpes Simplex Viruses On Several Fish Tissue Culture Systems.

APPROVED BY MEMBERS OF THE THESIS COMMITTEE:

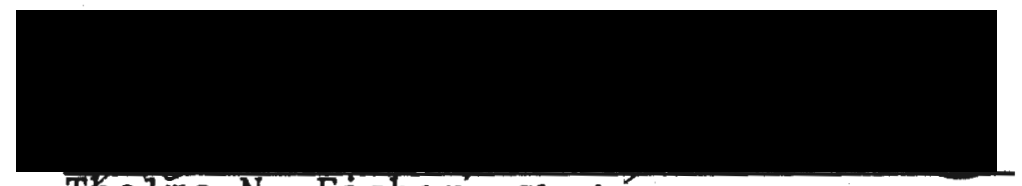

Thelma N. Fisher, Chairman
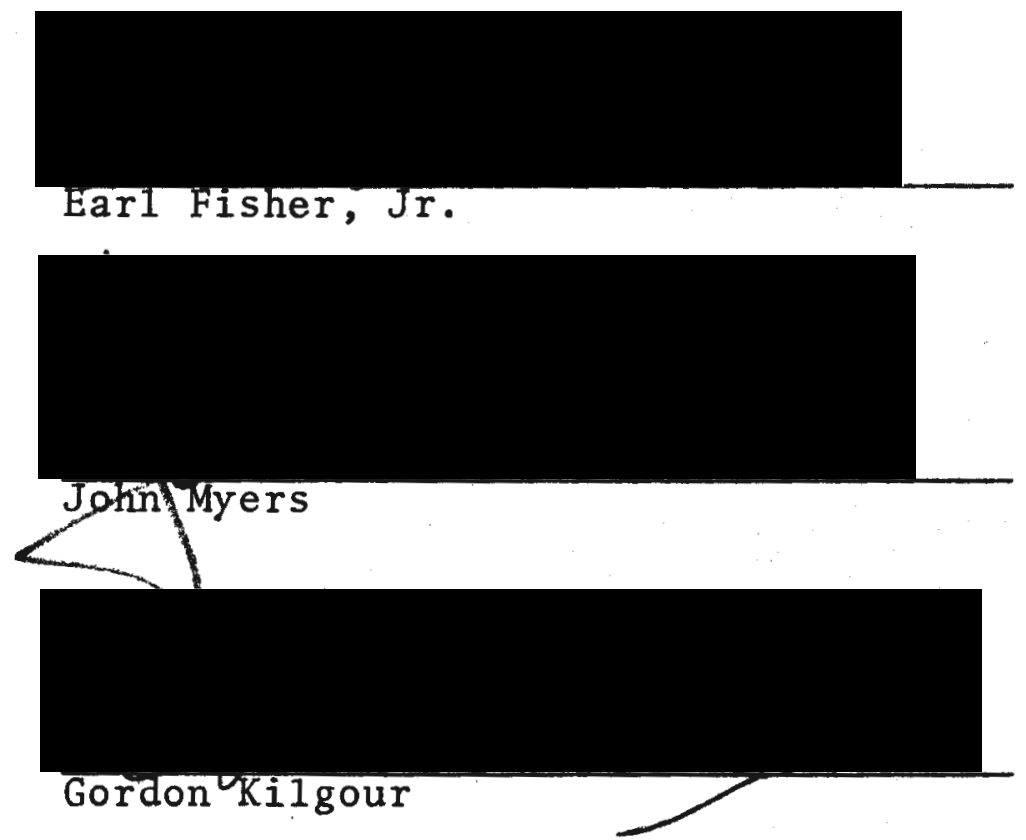

The purpose of this investigation was to observe changes induced by types 1 and 2 herpes simplex viruses (HSV 1 and HSV 2) when these viruses were cultivated in fish 
cel1s. The possibility of attempting to use human strains of herpesviruses in order to transform normal fish tissue culture preparations was considered. Three different fish cell cultures were tested: CHSE-214 cell lines were derived from embryonic chinook salmon (oncorhynchus tshawytscha), and STE-137 cell lines were obtained from embryonic stee1head trout (Salmo gairdneri). Cells isolated from immature ovaries of rainbow trout (Salmo gairdneri) were propagated by the investigator in these studies.

Both HSV 1 and HSV 2 demonstrated cytopathic effects on the 3 different cell types described above when these cells were observed during the exponential growth phase. If virus was added before cells were dividing actively, or when the cells were maintained in a stationary phase of growth, no effect was observed.

Several methods were employed in an attempt to transform fish cells grown in tissue culture. Different quantities of live virus, preparations of ultraviolet light inactivated virus and purified viral DNA were used in these studies but malignant conversion by known viral components was not achieved.

In these experiments, the $2 B$ strain of cells obtained originally from immature ovaries of rainbow trout appeared to undergo spontaneous transformation thereby becoming established as a permanent cell line. To date tissue cultures designated $2 \mathrm{~B}$ have undergone 25 transfers in this laboratory. 
EFFECTS OF TYPES 1 AND 2 HERPES SIMPLEX VIRUSES

ON SEVERAL FISH TISSUE CULTURE SYSTEMS

by

RAYMOND CHARLES HARRY

A thesis submitted in partial fulfillment of the requirements for the degree of

MASTER OF SCIENCE

in

BIOLOGY

Portland State University

1977 
TO THE OFFICE OF GRADUATE STUDIES AND RESEARCH:

The members of the Committee approve the thesis of Raymond Charles Harry presented 31 May 1977.
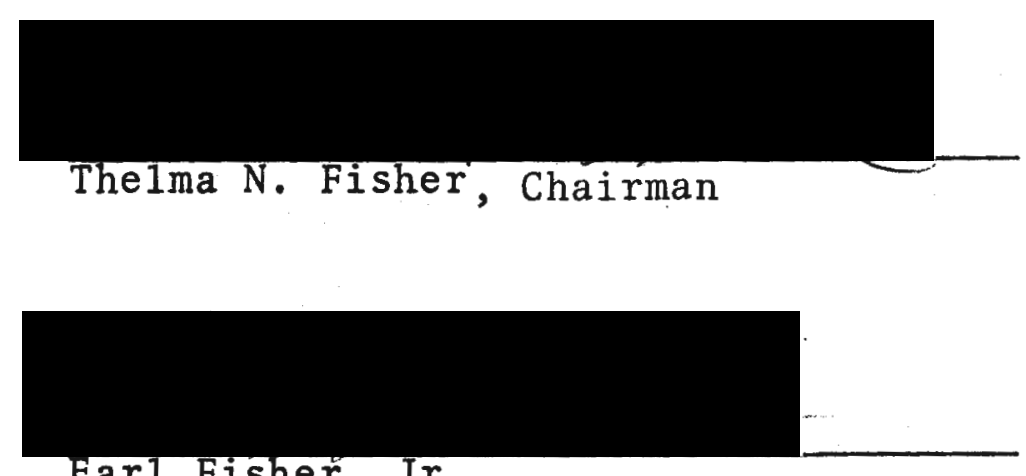

Earl Fisher, Jr.

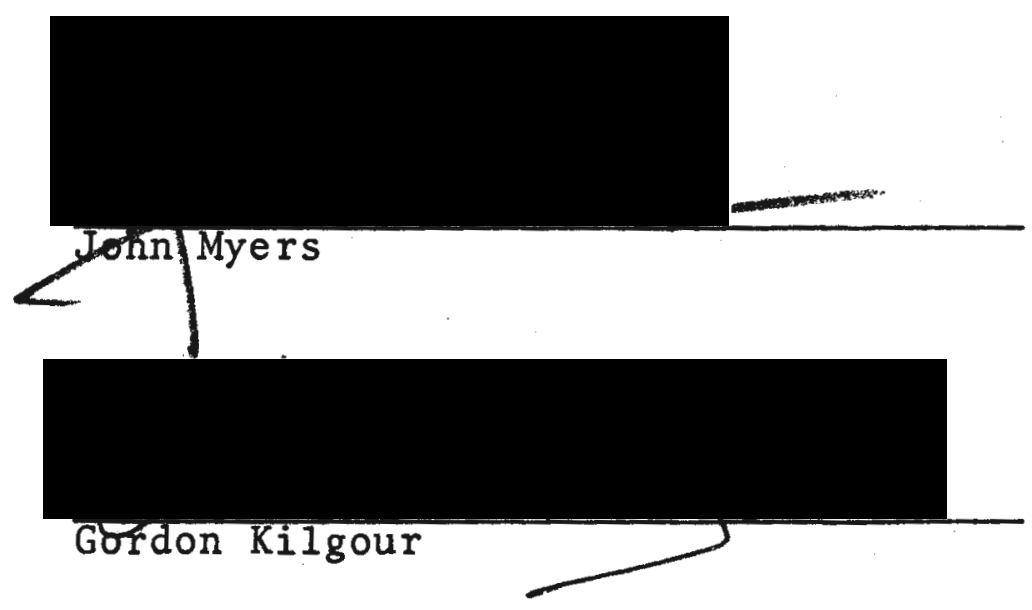

APPROVED :

W. Herman Taylor, Head, Bdology Department

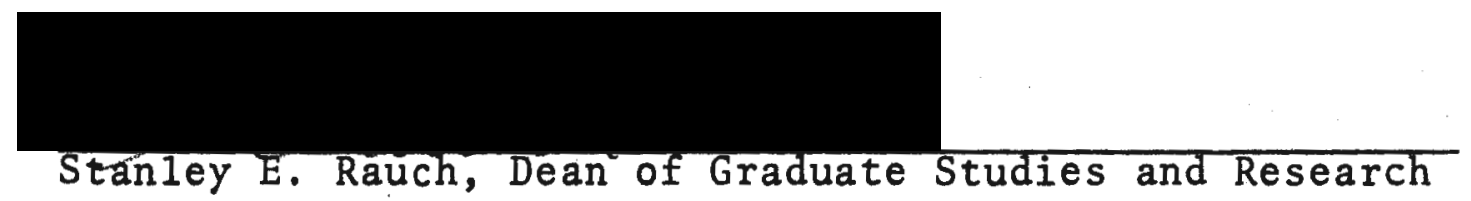




\section{ACKNOWLEDGEMENTS}

I am very grateful for the advice and guidance of my advisor, Dr. Thelma N. Fisher. I would also like to thank my committee members, Drs. Earl Fisher, Jr., John Myers, and Gordon Kilgour, for their help. I greatly appreciate the help from Dr. Richard Forbes in proofreading. 


\section{TABLE OF CONTENTS}

PAGE

ACKNOWLEDGEMENT S........................ i

LIST OF TABLES ........................ v

LIST OF FIGURES $\ldots \ldots \ldots \ldots \ldots \ldots \ldots \ldots \ldots \ldots \ldots \ldots \ldots \ldots \ldots$

INTRODUCTION.............................. 1

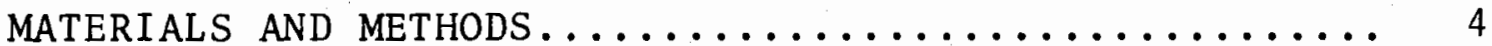

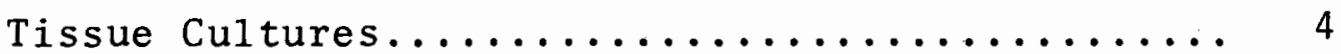

Media Used........................... 5

Subculturing Procedures................... 7

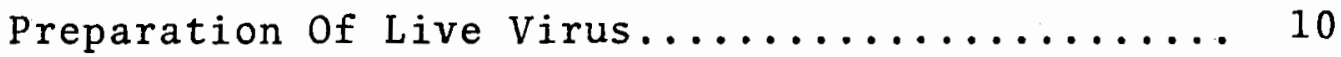

Live Virus Experiments................... 12

Preparation of Viral DNA.................. 14

Ultraviolet Light Inactivated Virus........... 18

RESULTS............................... 19

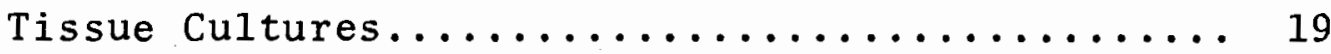

Live Virus Experiments.................. 20

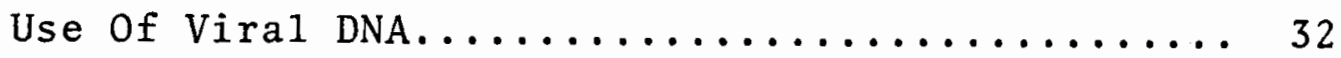

U1traviolet Light Inactivated Virus.......... 32

DISCUSSION ........................... 34

SUMMARY ............................. 37

BIBLIOGRAPHY ......................... 38 


\section{LIST OF TABLES}

TABLE

PAGE

I Formula of Hanks' Balanced Salt Solution, (10X) Stock Solution.................. 6

II Constituents of a Modified Eagle's Medium, Basal Medium, Used to Cultivate H.Ep. 2 Cer1s......................... 8

II Constituents of a Modified Eagle's Medium, Minimal Essential Medium (MEM), Used to Cultivate Fish Tissues................. 9 


\section{LIST OF FIGURES}

FIGURE

PAGE

1 A comparison of H.Ep. 2, STE-137, CHSE-214, and $2 \mathrm{~B}$ cell cultures photographed $48 \mathrm{hrs}$ after subculture and when cell sheets were confluent.................... 22

2 Demonstration of CPE by HSV-1 when virus infected H.Ep. 2, CHSE-214, and 2B cells... 27 


\section{INTRODUCT ION}

Many investigators were able to demonstrate that herpesviruses such as types 1 and 2 herpes simplex viruses which infect human subjects could transform a variety of animal cells, including hamster, rat, mouse, chicken, and human cells. Growth of herpes simplex virus (HSV) has been demonstrated in the following cell cultures: chick embryo, rabbit kidney, marmoset kidney, hamster kidney, Chinese hamster, feline kidney, HeLa, KB, H.Ep. 2, human amnion, rat lung, rabbit lung, human fibroblast, mouse fibroblast, Rous Sarcoma tissue, and tortoise kidney cells (10). In this investigation the effects of HSV-1 and HSV-2 on 3 fish tissue culture systems were studied.

Two of the fish cell cultures were obtained from Dr. J. Fryer (9) at Oregon State University, and one culture was isolated and propagated by this investigator. One of the Oregon State cultures designated CHSE-214 was derived from embryonic chinook salmon (oncorhynchus tshawytscha); the other culture designated STE-137 was obtained from embryonic steelhead trout (salmo gairdneri). The fish tissue culture system isolated by this investigator and designated $2 \mathrm{~B}$ was obtained from immature rainbow trout (salmo gairdneri) ovaries. Such fish cultures were subjected to live viruses, ultraviolet irradiated virus, and viral DNA in order to 
search for evidence typical of transformation processes.

Fong and Hsiung (7) used live guinea pig herpes-like viruses to transform hamster embryo cells. HSV destroyed cells in vitro so that it was necessary to provide some method whereby cell death was prevented so that HSV-induced transformation could be found (4). Several investigators used ultraviolet light irradiated herpesviruses to transform cell cultures $(5,18)$ while Aaronson and Todaro (1) used SV40 DNA to transform human dip1oid cells.

Rapp and Duff (17) reported that in their experiments $19 \%$ of HSV- 1 and $50 \%$ of HSV-2 strains tested transformed cells in culture, and that cells transformed by HSV-1 or HSV-2 following ultraviolet light treatment appeared to be epitheliod or fibroblastoid in morphology.

Officer (15) and Nims (14) studied the effects of selected mammalian viruses on fish cells. Officer (15) used the rainbow trout gonad (RTG) cell line to demonstrate its abilify to support the proliferation of 2 arboviruses, Venezuelan equine ecephalitis (VEE) virus and Eastern equine encephalitis (EEE) virus when cultivated at $22^{\circ}$. EEE virus caused more cytopathic effects than VEE virus; however both viruses multiplied in chick fibroblast (CF) cells at $22^{\circ}$ and attained higher titers in chick cells than in the fish cell lines studied. EEE virus was propagated also in embryo tissue of Gambusia, a viviparous fish (20). Studies by Nims (14) showed that chinook salmon cells and steelhead 
cells could support the growth of Western equine encephalitis with a virus yield as high as that observed in chick fibroblast cells. The virus of Newcastle disease was tested also but that virus did not replicate in the tissue culture systems studied.

This investigation was undertaken to determine if HSV posed an environmental threat to aquatic life, and in particular to salmonid fish by causing cell death or by transforming fish tissues into malignant new growths. It was necessary to look at the ability of fish cells to support the multiplication of human types of herpesviruses. If it was possible for HSV to multiply in fish tissues, an infectious cycle was considered possible. It was postulated that human subjects might infect fish (through sewage), and that HSV propagated by fish might reinfect humans. It was considered very important to determine the latter possibility since HSV-2 has been associated with cervical cancer according to epidemiological data $(5,13,19)$. In fact, Frenkel and associated (8) showed that human cervical tumor cells contained a fragment of HSV DNA in the host genome. Also the first evidence of the oncogenic potential of HSV1 was demonstrated by Duff and Rapp (6).

It was reasoned that if any of these cells could be transformed, altered properties could be observed and studied and information could be gained about the virus and the host regarding initial events critical in malignant conyersions. 


\section{MATERIALS AND METHODS}

\section{Tissue Cultures}

Three different types of fish cells were tested. Two cultures were obtained from Dr. Fryer (9), Oregon State University, and 1 cell culture was isolated from apparently normal rainbow trout gonadal tissue by this investigator. The Oregon State cell lines were labeled STE-137 and CHSE214. Strain STE-137 was from embryonic steelhead trout, while strain CHSE-214 was derived originally from embryonic chinook salmon. Numerous normal fish cultures obtained from immature ovaries of rainbow trout were propagated in this laboratory. The $2 \mathrm{~B}$ permanent cell line was established from one of these cultures.

Fish tissue culture cell line STE-137 is now in its $200^{\text {th }}$ passage, while fish cell type CHSE- 214 is in its $250^{\text {th }}$ passage. Both cell lines can be subcultured once weekly by preparing 4 new cultures from 1 bottle culture of the CHSE-214 ce11 line and by diluting STE-137 cultures 2 or 3 fold.

To obtain initial normal cultures as prepared by this investigator, rainbow trout were caught by hook and line from Swift Creek Reservoir in southwestern Washington. Ovaries were removed from the fish as aseptically as possible and these organs were placed in Hanks' balanced salt 
solution containing antibiotics (200 units penicillin and $.02 \mathrm{mg}$ streptomycin each per $\mathrm{m} 1$ ) for temporary storage and transport.

In the laboratory, tissue was washed in 3 successive baths of sterile Hanks' solution containing antibiotics. Ovaries were cut into small pieces, approximately $3 \mathrm{~mm}$ square, and placed in $30 \mathrm{ml}$ Falcon tissue culture flasks. Cells were allowed to adhere to plastic surfaces as preparations dried at room temperature. Medium was added when this condition was achieved. Originally culture medium was changed 3 times weekly, but experiments showed later that changing growth fluids once per week was sufficient. When cell sheets were confluent, cells were harvested by treating cultures with trypsin $[0.25 \%$ Difco $(1: 250)$ for 1 min at $\mathrm{pH}$ 7.5]. A 1:2 cell dilution (approximately $4 \mathrm{~m} 1$ of $1 \mathrm{x}$ $10^{6} \mathrm{ce} 11 \mathrm{~s} / \mathrm{m} 1$ ) was added to each of 2 flasks.

The permanent H.Ep. 2 cell line (human epitheloid cells obtained originally from a patient with carcinoma of the larynx) was used for the propagation of herpesviruses.

Tissue cultures were grown in $30 \mathrm{ml}$ plastic tissue culture flasks, or $200 \mathrm{ml}$ milk dilution bottles. All glassware was cleaned by means of standard tissue culture techniques.

Media Used

As recorded in Table I Hanks' balanced salt solution containing penicillin and streptomycin was used to suspend 
TABLE I

FORMULA OF HANKS' BALANCED SALT SOLUTION, (10X) STOCK SOLUTION

Solution A

Amount

$\mathrm{NaCl}$

$80 \mathrm{gm}$

KC1

$4 \mathrm{gm}$

$\mathrm{MgSO}_{4} \cdot 7 \mathrm{H}_{2} \mathrm{O}$

2. $\mathrm{gm}$

The above reagents were dissolved in about $300 \mathrm{ml}$ of double distilled. water.

Solution B

Amount

$\mathrm{KH}_{2} \mathrm{PO}_{4}$

$0.6 \mathrm{gm}$

$\mathrm{Na}_{2} \mathrm{HPO}_{4} \cdot 2 \mathrm{H}_{2} \mathrm{O}$

$0.6 \mathrm{gm}$

Glucose

$10 \mathrm{gm}$

These compounds were dissolved in approximately $300 \mathrm{ml}$ of double distilled water.

Solution C

Amount

$\mathrm{CaCl}_{2}$

$1.4 \mathrm{gm}$

Calcium chloride was dissolved in $200 \mathrm{~m} 1$ of double distilled water and added to Solutions $A$ and $B$.

Solution D

Amount

Phenol Red $0.2 \%, 100 \mathrm{~m} 1$

The final volume was brought to $1,000 \mathrm{~m} 1$ and the solution was sterilized by Sietz Filtration. The 10 times concentrated Hanks' solution was stored at $4^{\circ}$ until the dilute Hanks" preparation was required. 
a11 ce11 cultures. Appropriate nutrients were added to the basal solution for growth studies. Because H.Ep. 2 cel1s were malignant, they required fewer growth factors than fish cell cultures. Medium used to cultivate H.Ep. 2 cells consisted of Basal Medium as described in Table II. When viuses were propagated in these cells $10 \%$ rabbit serum was added instead of calf serum. Culture medium was changed the $4^{\text {th }}$ and $6^{\text {th }}$ days after subculturing. Subcultures were made on the $7^{\text {th }}$ day.

Fish cells were not malignant; therefore they required more components for growth. Non-essential amino acids as we11 as double strength amino acids, vitamins, and L-glutamine stimulated proliferation. Growth experiments showed that fish cells grew best when $10 \%$ fetal bovine serum was included in culture fluids, but they grew well when $10 \%$ calf serum was used also. Culture medium was changed once week1y. This medium was designated Eagle's minimum essential medium (Table III).

\section{Subculturing Procedures}

Cultures were subcultured by the addition of $3 \mathrm{ml}$ of $0.25 \%$ trypsin (Difco 1:250) mixed in Hanks' balanced salt solution adjusted to $\mathrm{pH}$ 7.5. Trypsin solutions were allowed to remain on cell sheets for 1 min, after which time fluids were removed by aspiration. Cultures were held at room temperature for approximately $15 \mathrm{~min}$, or until cell sheets began to detach from glass or plastic surfaces. Five ml of 
TABLE II

CONSTITUENTS OF A MODIFIED EAGLE'S MEDIUM, BASAL MEDIUM, USED TO CULTIVATE H.Ep. 2 CELLS

Materials

Hanks' Balanced Salt Solution

Calf Serum or Rabbit Serum (Flow Laboratories Inactivated at $56^{\circ}$ for 30 $\min$.)

Amino Acids (100x, F1ow Laboratories)

Vitamins (100x, Flow Laboratories)

Penicillin [Stock Solution: 20,000 Units per m1 (Pfizer Laboratories)]

Streptomycin [Stock Solution: $20 \mathrm{mg}$ per $\mathrm{ml}$ (Pfizer Laboratories)]

$5 \% \mathrm{NaHCO}_{3}$

L-glutamine (100x, Flow Laboratories)
Amount

$85 \mathrm{~m} 1$

$10 \mathrm{~m} 1$

$1 \mathrm{~m} 1$

$1 \mathrm{~m} 1$

$1 \mathrm{~m} 1$

$1 \mathrm{~m} 1$

$2 \mathrm{ml}$

$1 \mathrm{~m} 1$ 
CONSTITUENTS OF A MODIFIED EAGLE'S MEDIUM, MINIMAL ESSENTIAL MEDIUM (MEM), USED TO CULTIVATE FISH TISSUES

Materials

Hanks' Balanced Salt Solution

Calf Serum or Fetal Bovine Serum (Flow

Laboratories, Inactivated at $56^{\circ}$

for $30 \mathrm{~min}$.

Amino Acids (100x, Flow Laboratories)

Vitamins (100x, Flow Laboratories)

Non-Essentia1-Amino Acids (100x, Flow

Laboratories)

Penicillin [Stock Solution 20,000 Units

per ml (Pfizer Laboratories)]

Streptomycin [Stock Solution: $20 \mathrm{mg}$ per

m1 (Pfizer Laboratories)]

$5 \% \mathrm{NaHCO}_{3}$

L-glutamine (100x, Flow Laboratories)
$1 \mathrm{~m} 1$

$3 \mathrm{mI}$

Amount

$85 \mathrm{~m} 1$

$10 \mathrm{~m} 1$

$2 \mathrm{~m} 1$

$2 \mathrm{mI}$

$1 \mathrm{~m} 1$

$1 \mathrm{~m} 1$

2. $\mathrm{mI}$ 
of medium was added to bottle contents and this mixture was drawn up and down several times in the pipet in order to separate cells.

H.Ep. 2 and CHSE- 214 preparations were plated at $1 x$ $10^{6}$ cells per bottle, while STE -137 cells were plated at 2 $x 10^{6}$ cells per bottle. The $2 \mathrm{~B}$ cultures required an even larger inoculum in order to achieve growth so that $3 \times 10^{6}$ cells of $2 \mathrm{~B}$ cultures were added to bottles initially. This was true also for the normal cultures.

Preparation of Live Virus

Originally human herpesviruses types 1 and 2 were obtained from the American Type Culture Collection, Bethesda, Maryland. Viruses were grown occasionally on chick embryos in order to provide stock seed virus and to increase virus titers. Windows were drilled in 11-day old chick embryos after which chorioallantoic (CAM) membranes were dropped. Different dilutions of virus were added to exposed membranes and cultures were allowed to incubate 2 days at $35^{\circ}$. After 2 days membranes were observed for pox-like lesions. Membranes displaying a large number of infectious centers were removed surgically by cutting membranes with sterile scissors and infected preparations were transferred to sterile, cold mortars. Mortars containing membranes were frozen at $-70^{\circ}$. After freezing, sterile alundum and a small amount of sterile tryptose broth were added to 
mortars, and membranes were homogenized with a pestle in order to release virus. Additional broth and antibiotics were included in this mixture in order to be free of microbial contamination and to facilitate pipetting. The solution was pipetted into a sterile centrifuge tube and preparations were centrifuged at 1 ow speed $(3,020 \mathrm{x}, 15 \mathrm{~min})$ in order to separate alundum and membrane debris from the virus-containing supernatant fluids. Virus preparations were transferred to sterile glass ampules which were sealed, and held frozen at $-70^{\circ}$.

Before virus was used for experiments, it was passed at least 1 time in tissue culture (H.Ep. 2). This was done in order to be free of some of the debris left in stock culture fluids, to check for sterility, and to increase virus titer.

When growing virus in tissue culture, rabbit serum was included instead of calf serum because rabbits were thought to contain fewer antibodies than calves do against herpesviruses. Antibodies to herpesviruses in serum would inactivate the viral agent.

When cells were barely confluent, a $1 \mathrm{ml}$ volume of virus was added to tissue culture preparations. Cultures were held at room temperature for $2 \mathrm{hrs}$ because herpesvirus absorbs to cells best at lower temperatures. Cultures were incubated at $37^{\circ}$ and observed for cytopathic effect (CPE). HSV-1 normally demonstrated CPE in $48 \mathrm{hrs}$ 
while HSV-2 required approximately $96 \mathrm{hrs}$. When cells demonstrated a CPE known as plaques, and a rounding-up of cells appeared which was more pronounced in test than in control systems, cultures were placed at $-70^{\circ}$.

Cultures were frozen and thawed 3 times in order to lyse cells for the release of intracellular viruses. Preparations were centrifuged at low speed $(3,020 \mathrm{x}, 15 \mathrm{~min})$ in order to remove H.Ep. 2 cellular debris. Supernatant fluids containing viruses were transferred to sterile containers and stored at $-70^{\circ}$.

Before any virus preparation was used in an experiment, the titer (10west virus dilution showing CPE in H.Ep. 2 cells grown in tissue culture) was determined. When assaying for viral titers, procedures were carried out in triplicate. All virus preparations showed cytopathic effects when herpesviruses were tested at dilutions of $1: 64$ or higher.

Live Virus Experiments

For live virus experiments, varying quantities of viral preparations were added to the 3 types of fish cultures at different times following subculture. Such a procedure was followed in order to decide whether or not live virus could serve as a transforming agent. It was necessary to determine various effects which such viruses might have on cell cultures. These experiments were done at $19^{\circ}$ in 
media containing $10 \%$ calf, $10 \%$ rabbit, or $10 \%$ fetal bovine sera.

Volumes of 1,2 , and $2.5 \mathrm{ml}$ of virus were added to different tissue culture preparations. There were 2 controls included throughout; one control tube contained no additives, while the other control received H.Ep. 2 supernatant growth fluid.

Virus was included in cultures showing varying degrees of confluency at different time intervals following subculture. Virus was added at 1,2 , and 5 day intervals after subculture.

To determine whether or not human strains of herpesviruses could multiply in fish cells grown in tissue cultures, another experiment was conducted. After inoculation with virus, the same procedure to recover the agent from H.Ep. 2 cells was followed in order to obtain herpesvirus from fish cells. Titration on chorioallantoic membranes of 11-day chick embryos to determine if viral replication occurred was carried out. A control for this experiment consisted of an equal aliquot of viral inoculum as used in the test system which was diluted to the same final volume as that prepared for the culture. Incubation conditions for control and test systems were the same throughout the experiment. 
Preparation of Viral DNA

HSV-1 and HSV-2 DNA were isolated by the following method developed originally by Marmur and modified by Fisher (6) to be suitable for tissue culture studies.

1. Ten bottle cultures $\left(10^{6}\right.$ cells per bottle) of H.Ep. 2 cells were allowed to grow until cell sheets were barely confluent.

2. One $\mathrm{ml}$ of a high titered virus preparation was added to each bottle culture. Herpesvirus was allowed to absorb to cell sheets for 2 hrs at room. temperature. Cultures were moved to a $35^{\circ}$ incubator and these were retained there until plaques and marked cytopathic effect developed (24-96 hrs).

3. Infected cell, sheets were removed by scraping glass covered surfaces with a rubber policeman; cell preparations were pooled and the total volumes recorded. Enough $10 \mathrm{X}$ saline-citrate solution ( $1.5 \mathrm{M} \mathrm{NaCl}$ and $0.15 \mathrm{M}$ trisodium citrate, $\mathrm{pH}$ 7.0) was added in order to achieve a final $1 X$ concentration of the saline-citrate preparation. Example: total volume at harvest was 1,240 $\mathrm{ml}$. Finally $140 \mathrm{ml}$ of $10 \mathrm{X}$ saline-citrate solution was added to the above preparation so that the new total volume was 1,380 $\mathrm{m} 1$.

4. Preparations were subjected to 1 "freeze and thaw" cycle. 
5. Samples were centrifuged $15 \mathrm{~min}$ at $4,080 \mathrm{x} \mathrm{g}$ in a Sorval centrifuge. Supernatant fluids were retained.

6. Supernatant fluids were centrifuged $2 \mathrm{hrs}$ at $55,000 \times \mathrm{g}$ in the L2-65 Spinco ultracentrifuge. Sedimented pellets from this centrifugation were pooled in $10 \mathrm{~m} 1 \mathrm{di}$ lute saline-citrate $(1 X)$ solution.

7. RNase, $0.3 \mathrm{ml}$ per tube: $2 \mathrm{mg}$ per $\mathrm{m} 1$ stock or $2000 \mathrm{ug} / \mathrm{ml}$ was added and the mixture was held $30 \mathrm{~min}$ at $37^{\circ}$.

8. DNase treatment was omitted.

9. Samples were centrifuged again in the Spinco L2-65 ultracentrifuge for $2 \mathrm{hrs}$ at $55,000 \mathrm{x}$. Pellets were retained since they contained viral components.

10. Pellets were eluted in appoximately $10 \mathrm{ml}$ salinecitrate solution per tube and these samples were pooled in a $500 \mathrm{ml}$ Erlenmeyer flask. Viral protein coat remained with viral DNA at this point in the procedure.

11. Two $\mathrm{m} 1$ of $25 \%$ sodium 1 auryl sulfate was added to viral preparations. Samples were heated $10 \mathrm{~min}$ at $60^{\circ}$ at which time samples turned viscous.

12. Samples were allowed to cool; the total volume was measured and enough solid sodium perchlorate was added in order to obtain a final concentration of IM. (IM perchlorate $=14.1 \mathrm{~g}$ per $100 \mathrm{ml})$. This treatment helped dissociate protein coat from viral nucleic acid.

13. An equal volume of $24: 1$ chloroform:isoamy 1 alcohol mixture was added to test samples. It was necessary 
to shake preparations vigorously and frequently for $30 \mathrm{~min}$ after preparations were placed in $100 \mathrm{~m} 1$ ground $\mathrm{glass}$ stoppered cylinders. On subsequent extractions samples were agitated for 15 min. Chloroform deproteinized preparations and provided surface denaturation while isoamyl alcohol reduced foaming and stabilized the recovered layers. 14. Samples were centrifuged $10 \mathrm{~min}$ at $4,080 \times \mathrm{g}$ in glass or plastic containers. Aqueous layers were removed and the volumes were measured. An equal volume of $24: 1$ chloroform:isoamyl alcohol mixture was added again and samples were agitated $15 \mathrm{~min}$. At this step in the procedure it was possible to hold samples overnight in the refrigerator $\left(4^{\circ}\right)$.

15. Samples were centrifuged $10 \mathrm{~min}$ at $4,080 \mathrm{xg}$ in glass conicals. Upper aqueous layers were removed and the extraction procedure was repeated.

16. Samples were treated once again with RNase in order to be rid of contaminating RNA. At this time it was essential that RNase was treated as follows: RNase (0.2\%) was heated in $0.5 \mathrm{M} \mathrm{NaCl}, \mathrm{pH} 5.0$ at $80^{\circ}$ for $10 \mathrm{~min}$. Stock RNase was prepared to contain $2000 \mathrm{ug} / \mathrm{ml}$; a final concentration of $50 \mathrm{ug} / \mathrm{ml}$ was required. This value amounted to a 1-40 dilution of the heated stock RNase solution. For computation purposes it was assumed that the total volume to be treated was $15 \mathrm{~m} 1$. Therefore, $1 / 40=\mathrm{X} / 15 ; \mathrm{X}=$ $0.375 \mathrm{ml}$ heated stock RNase which could be added to a 15 
m1 solution of DNase.

17. Samples containing heat-treated RNase were heated $30 \mathrm{~min}$ at $37^{\circ}$. Samples were cooled and deproteinized again with an equal volume of chloroform:isoamyl alcohol mixture. Preparations were agitated $15 \mathrm{~min}$, then centrifuged $10 \mathrm{~min}$ at $4,080 \mathrm{xg}$ in $50 \mathrm{ml}$ glass conicals.

18. Aqueous supernatant fluids were saved and the volumes were measured. Two volumes of absolute ethanol were used to overlay DNA preparations. Samples were held overnight at $4^{\circ}$ in glass centrifuge bottles. Native DNA should have coiled around a glass rod in fibers. Denatured DNA formed a precipitate when centrifuged. Samples were centrifuged $30 \mathrm{~min}$ at $4,080 \mathrm{x} \mathrm{g}$ in a Sorval centrifuge. Supernatant fluids were decanted and discarded; precipitates were retained and dissolved in small volumes (1-2 m1) of $1 X$ saline-citrate solution.

The precipitate collected was dissolved in a small amount of saline-citrate solution and this preparation was added to fish cells known to be multiplying in the exponential phase of growth. Various dilutions of viral DNA solutions were tested also. As a control measure, sterile saline-citrate alone was added to uninfected cell cultures.

The same basic procedure as described above was used to recover H.Ep. 2 cellular DNA. As controls, concentrated preparations as well as various dilutions of H.Ep. 2 cellular DNA were added to fish cultures. 
U1traviolet Light Inactivated Virus

Duff and Rapp (4) demonstrated that ultraviolet treated HSV-2 transformed hamster embryo fibroblasts. Therefore $2 \mathrm{~m} 1$ of virus solution was placed in $60 \mathrm{~mm} \mathrm{glass}$ petri dishes (held on ice) with an ultraviolet light source suspended 18 ins above the samples. Suspensions were exposed to ultraviolet light for 30 secs, and for $1,2,3,4$, $5,10,15,20,25,30,35,40,45,50,55$, and $60 \mathrm{~min}$ intervals.

Samples were mixed frequently during the ultraviolet light exposure procedure. One-tenth $\mathrm{ml}$ of the above solutions were inoculated in each of 3 tissue culture tubes which contained H.Ep. 2 cells. Assay was made in order to determine the time interval when $\mathrm{CPE}$ due to viral infection was inhibited by ultraviolet light. Three time intervals before and one interval following the observed period when total inhibition of CPE was achieved were selected as test intervals for future studies in attempts to achieve transformation.

Large batches of virus were exposed to ultraviolet light according to above schedules, in order to prepare inocula for the fish tissue cultures. 


\section{RESULTS}

\section{Tissue Cultures}

In these investigations it was necessary to prepare a normal fish cell culture in order to compare it in transformation studies with the other 2 fish cell lines which were considered to be established since they grew continously in tissue culture. One important aspect of note concerning the established cell lines was that these cultures had made a spontaneous malignant conversion prior to this study since they were shown to multiply continuously. Therefore, in order to achieve and to be able to detect transformation processes in the presence of viral DNA, it was necessary to begin experiments with cells obtained from animals thought to be unaffected by agents such as foreign nucleic acids. In addition to continuous growth in culture other wel1-known gross aspects observed in malignant transformation of tissue culture systems were as follows: shortening of generation time in conjunction with an unusual chromosome picture, the presence of abnormal chromosomes such as those showing deletions, constrictions, breaks and pulverization, the loss of contact inhibition, and the ability of altered cells to form tumors when introduced into susceptible animals. With these views in mind, approximately 100 different sets of gonadal cultures were 
initiated from 10.0 different fishes.

In the process of this investigation, one of the cultures appeared to have undergone a spontaneous transformation because it could be subcultured indefinitely. This culture was obtained from the second fish (2) and from the second culture flask (B). To date it has been propagated in the laboratory for almost 3 years during which time it has undergone 25 subcultures (Fig. 1a, b, $c, d)$.

\section{Live Virus Experiments}

If either HSV-1 or HSV-2 were used to inoculate any of the 3 different fish cell lines at the proper time, CPE could be demonstrated (Fig. 2). The proper time appeared to be at approximately $48 \mathrm{hrs}$ when cells were multiplying in the exponential growth phase.

When the 3 varying volumes $(1,2$, and $2.5 \mathrm{~m} 1)$ of either type of herpesvirus served as inoculum for any of the exponentially growing fish cultures, CPE was demon strated. No effect was observed when appropriate volumes such as $1,2,2.5$, and $5 \mathrm{ml}$ of H.Ep. 2 supernatant growth fluids were included in fish tissue culture preparations. If either virus was added to cultures when cells had just become attached to glass, when cell sheets were nearly confluent, or when cell sheets were definitely confluent, no effect was detected. Likewise there was no effect when 
H.Ep. 2 cell supernatant growth fluids were added to comparable systems. 
Figure 1. A comparison of H.Ep. 2, STE-137, CHSE214 , and 2B cell cultures photographed $48 \mathrm{hrs}$ after subculture and when cell sheets were confluent.

Photographs were taken of uninfected cultures to demonstrate the morphology of cells. H.Ep. 2 (Fig. la) and STE-137 (Fig. lb) were epithelial-like, while CHSE214 (Fig. 1C) resembled fibroblasts and 2B (Fig. 1d) appeared to be a mixture of cell types. Photographs were taken with a Nikon Research microscope using Kodak Panotomic $X$ film developed with Kodak Microdol $X$ developer. Prints were made with Kodak Polycontrast paper using Dektol developer. Magnification $\times 350$. 


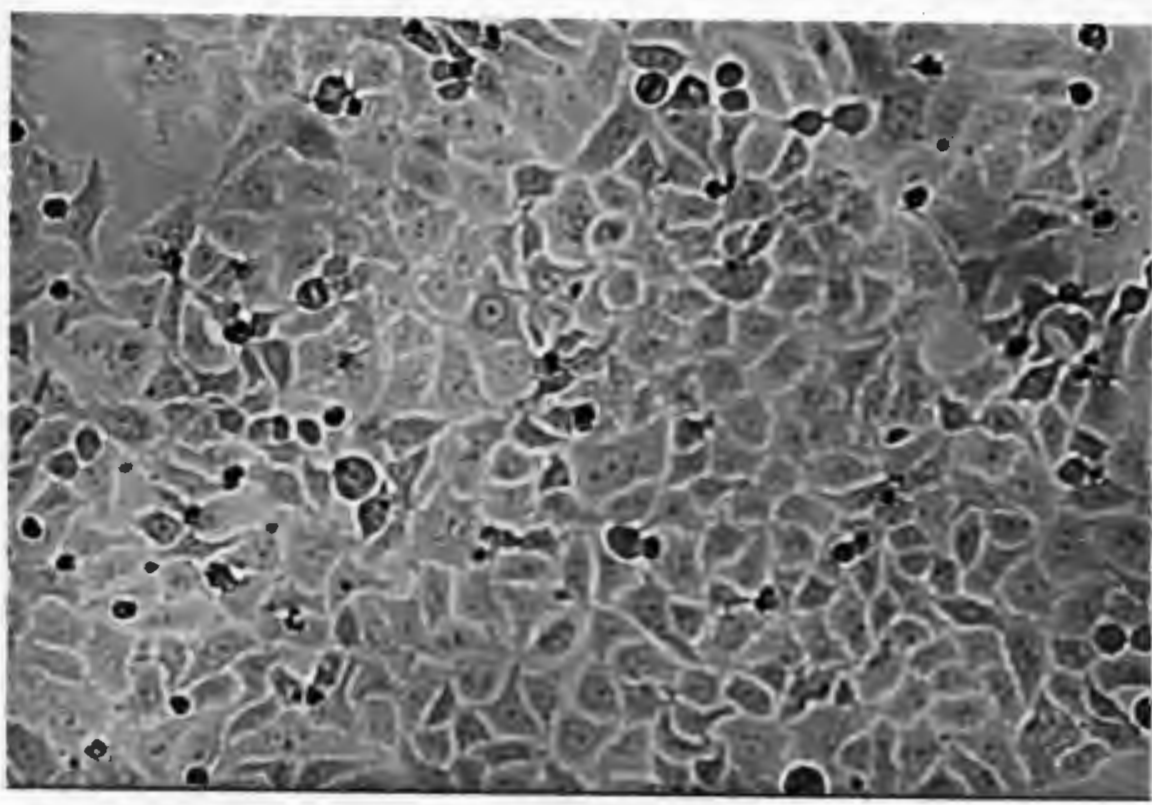

\begin{tabular}{c}
1 \\
1 \\
0 \\
2 \\
-1 \\
4 \\
0 \\
0 \\
1 \\
0 \\
-1 \\
\hline
\end{tabular}

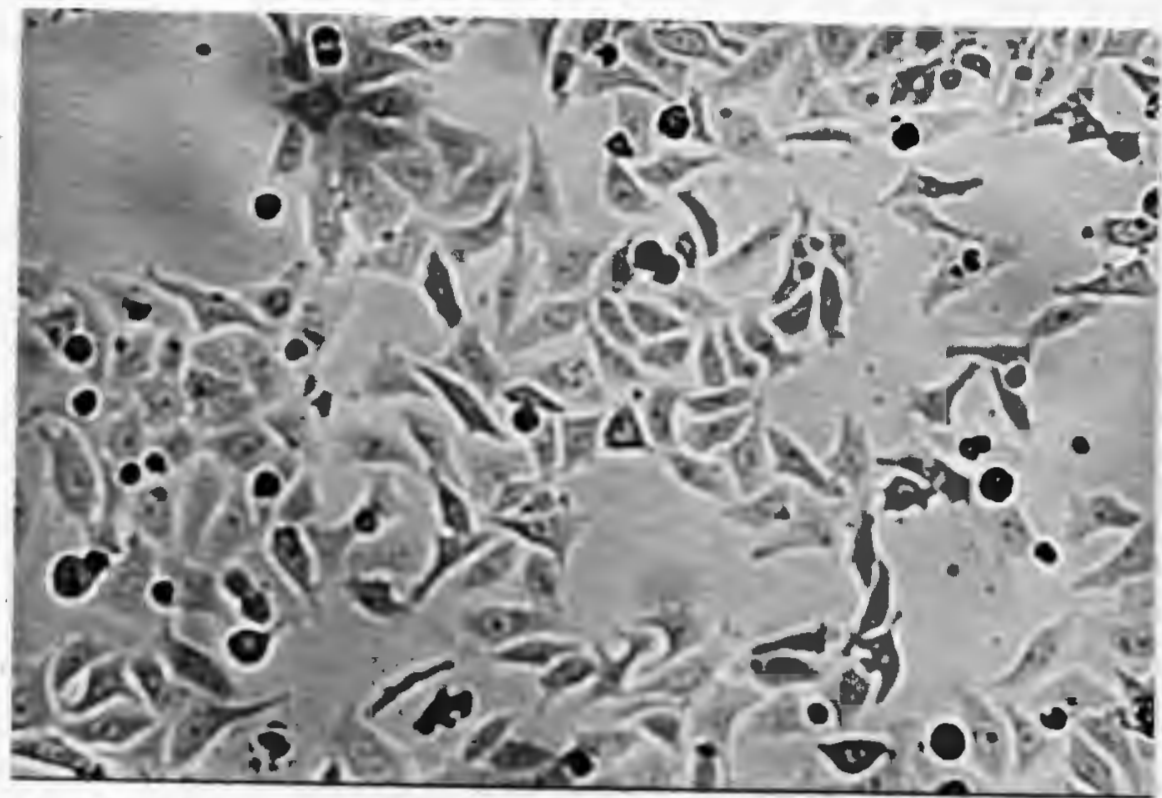

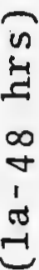




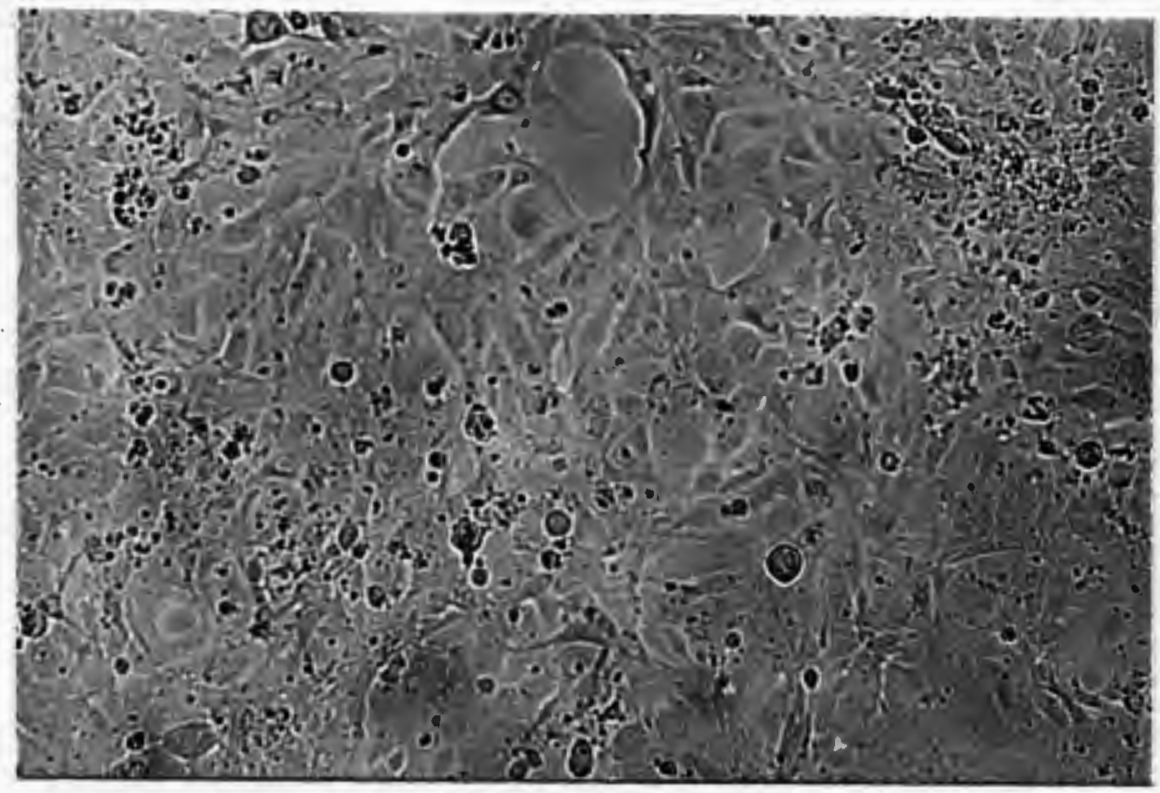

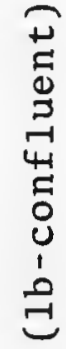

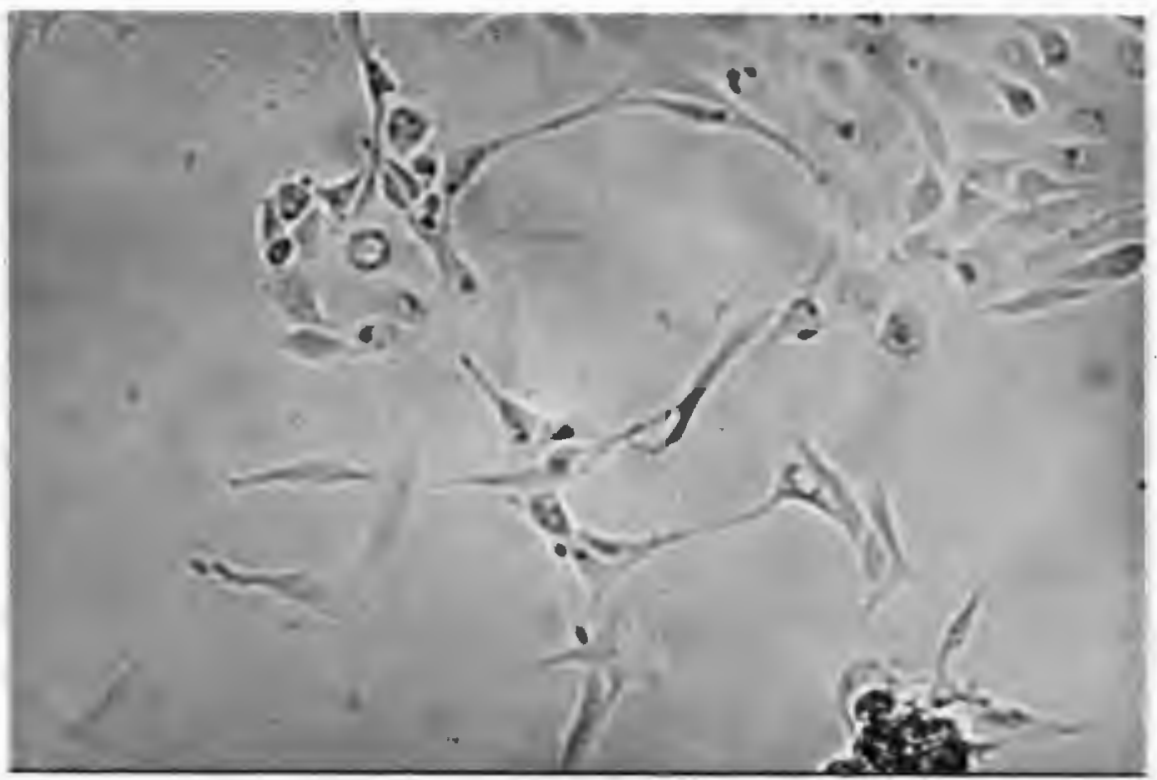

n
$=$
$=$
+
$\vdots$
$\vdots$ 


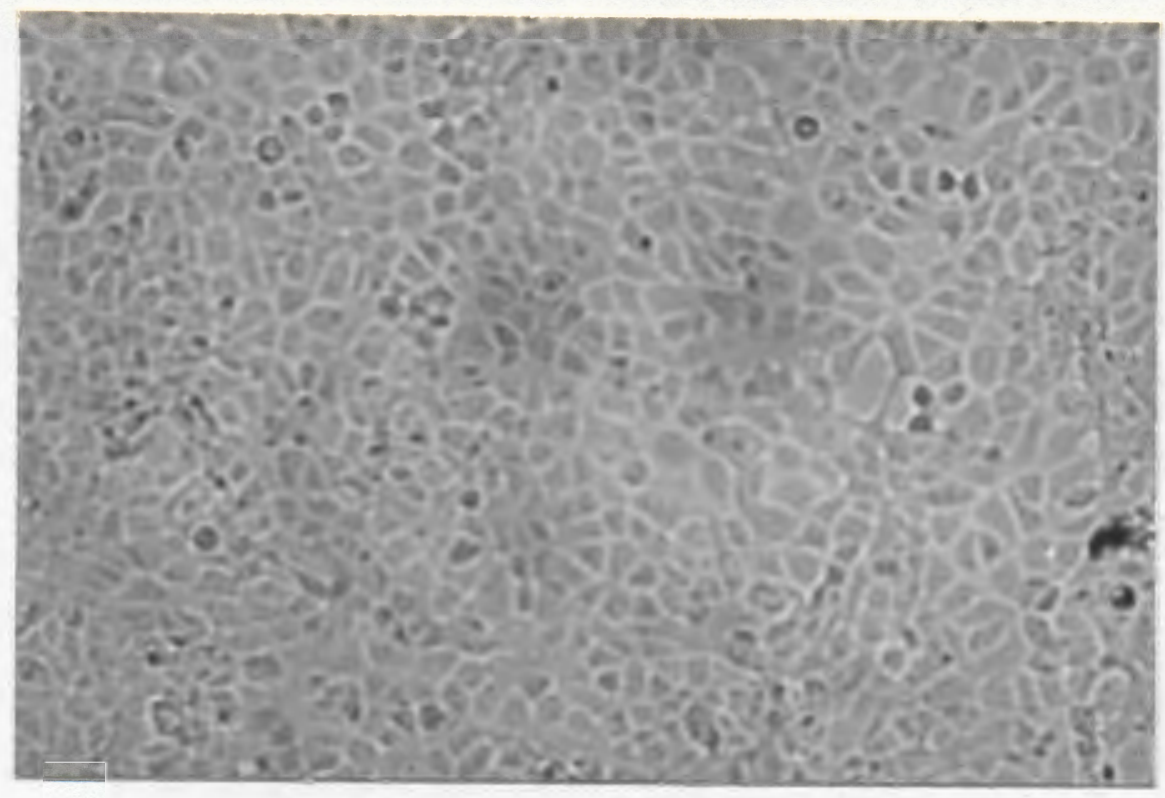

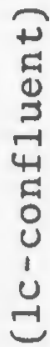

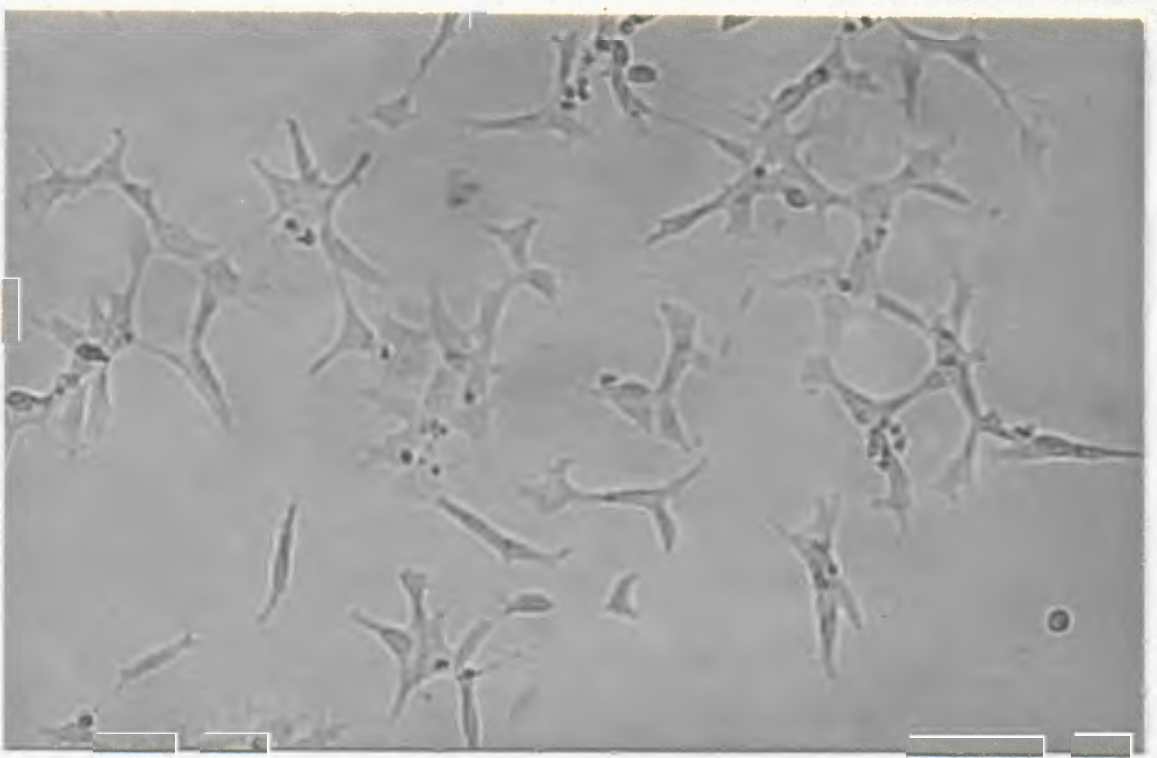

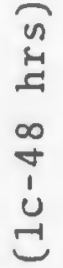




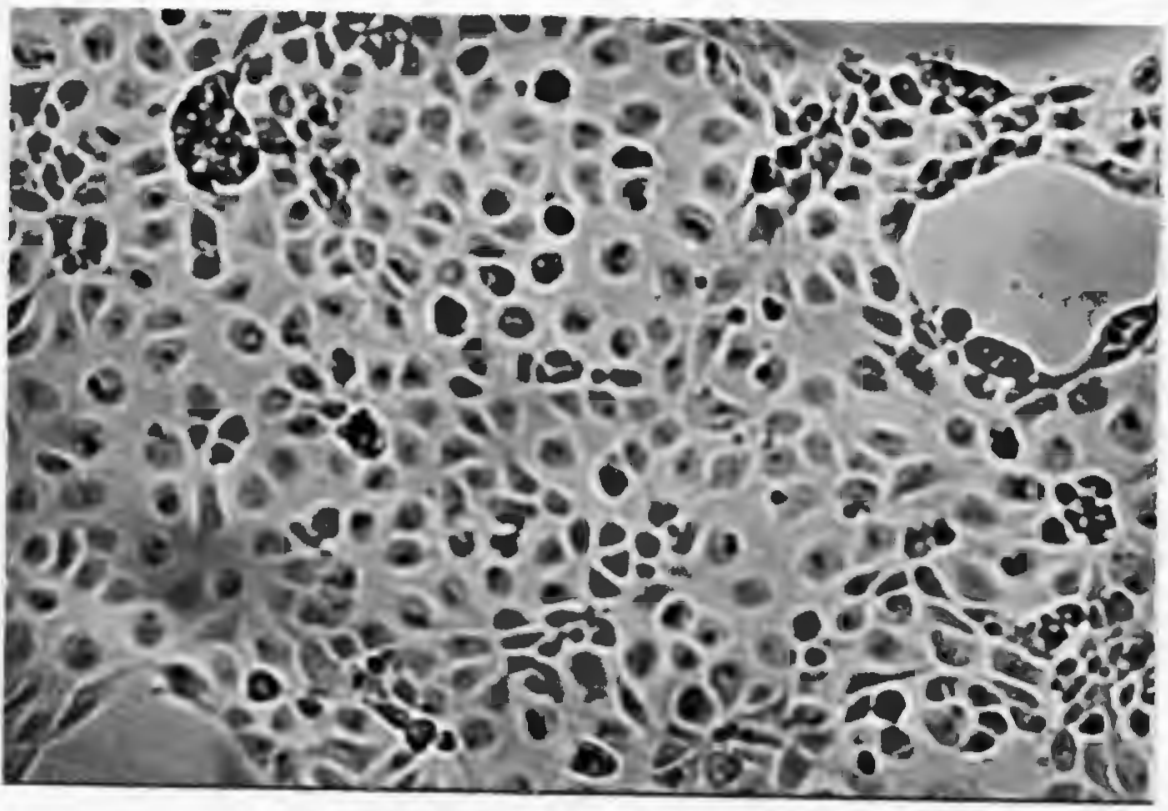

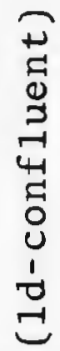

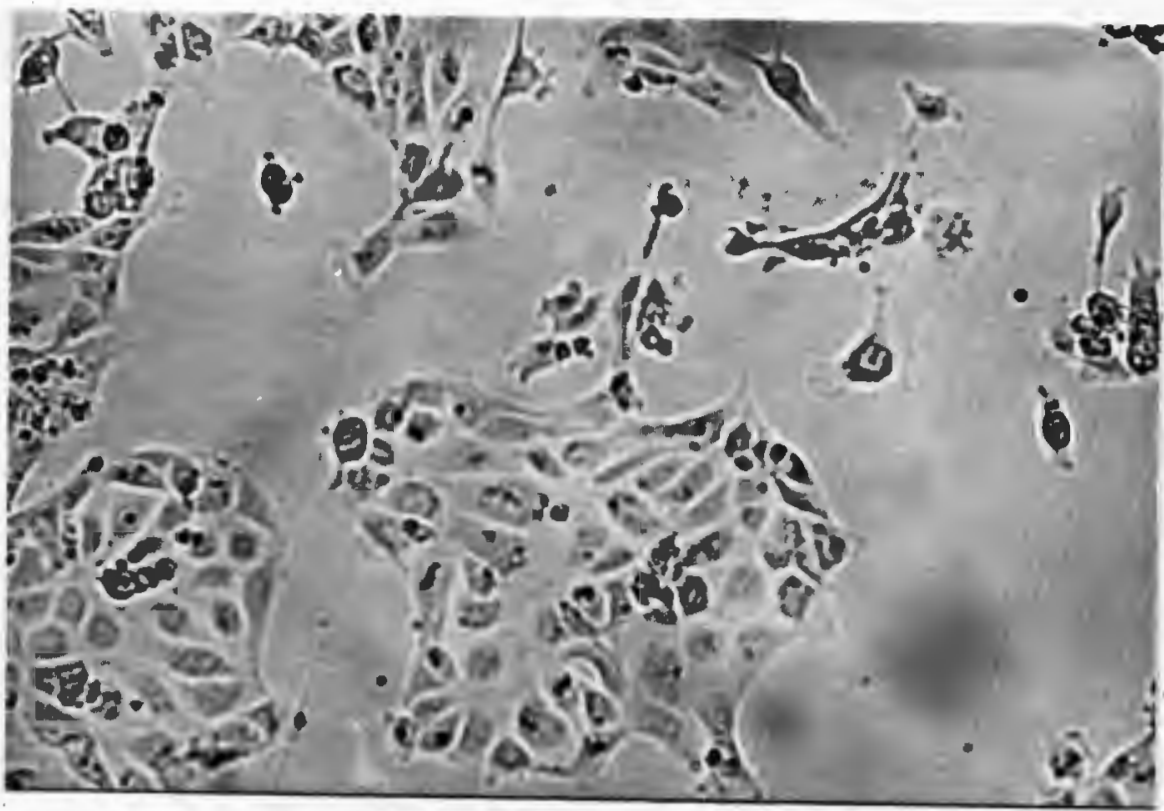


Figure 2. Demonstration of CPE by HSV-1 when virus infected H.Ep. 2, CHSE- 214 and $2 \mathrm{~B}$ cells.

In this study varying amounts $(1,2$, or $2.5 \mathrm{ml})$ of either HSV-1 or HSV-2 were added to actively growing cultures of H.Ep. 2, STE-137, CHSE-214, or 2B ce11s. These photographs demonstrated the cytopathic effect when HSV-1 infected cell cultures of H.Ep. 2, CHSE-214, or 2B cells. CPE was also observed when cultures were infected with HSV-2. Magnification $\times 350$.

(1a) H.Ep. 2 cells, control

(1b) H.Ep. 2 cells infected with HSV-1

(2a) CHSE-214 cel1s, control

(2b) CHSE-214 cells infected with HSV-1

(3a) $2 \mathrm{~B}$ cells, control

(3b) 2B cells infected with HSV-1 


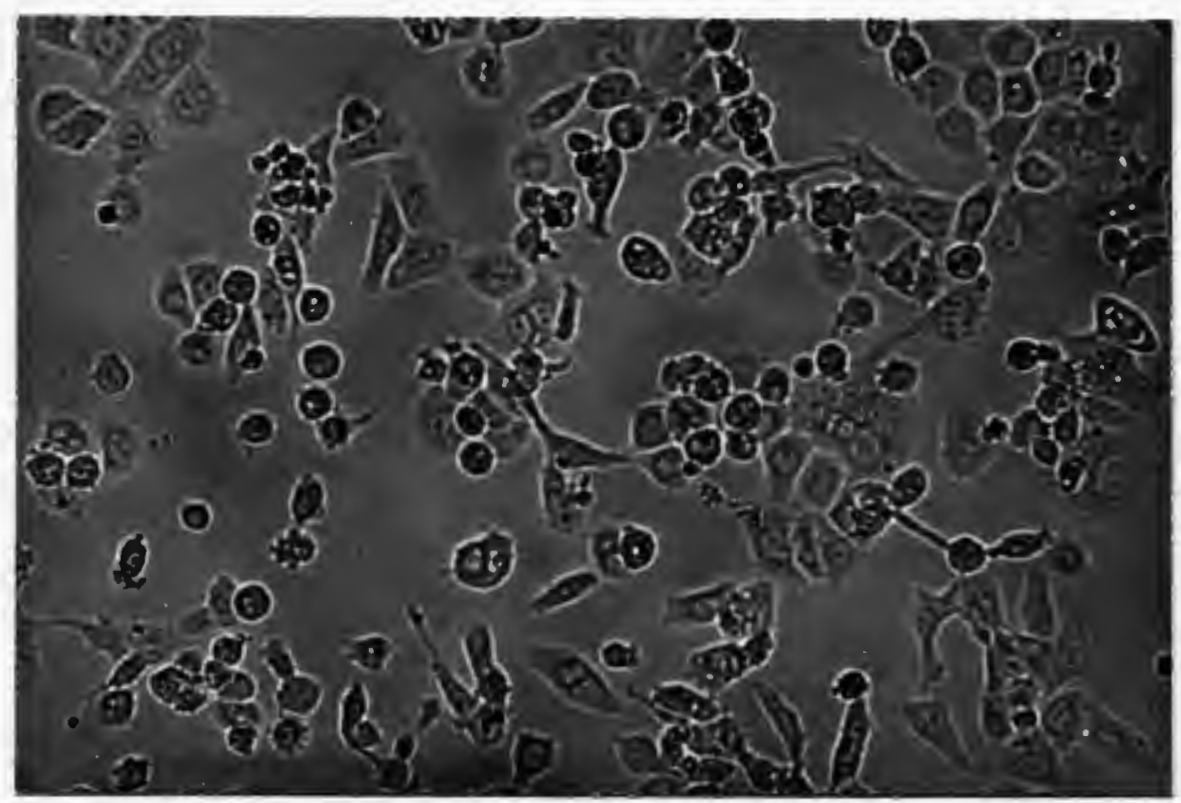

를

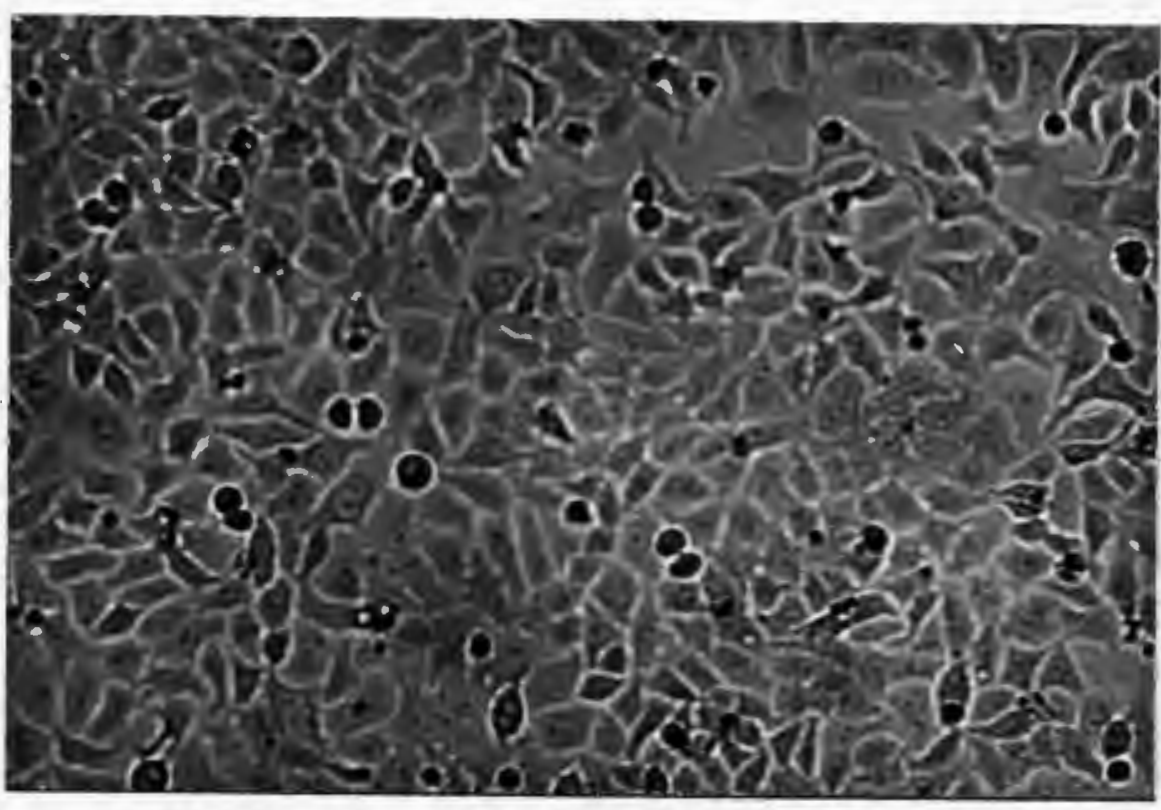

$\underset{\pi}{ت}$ 


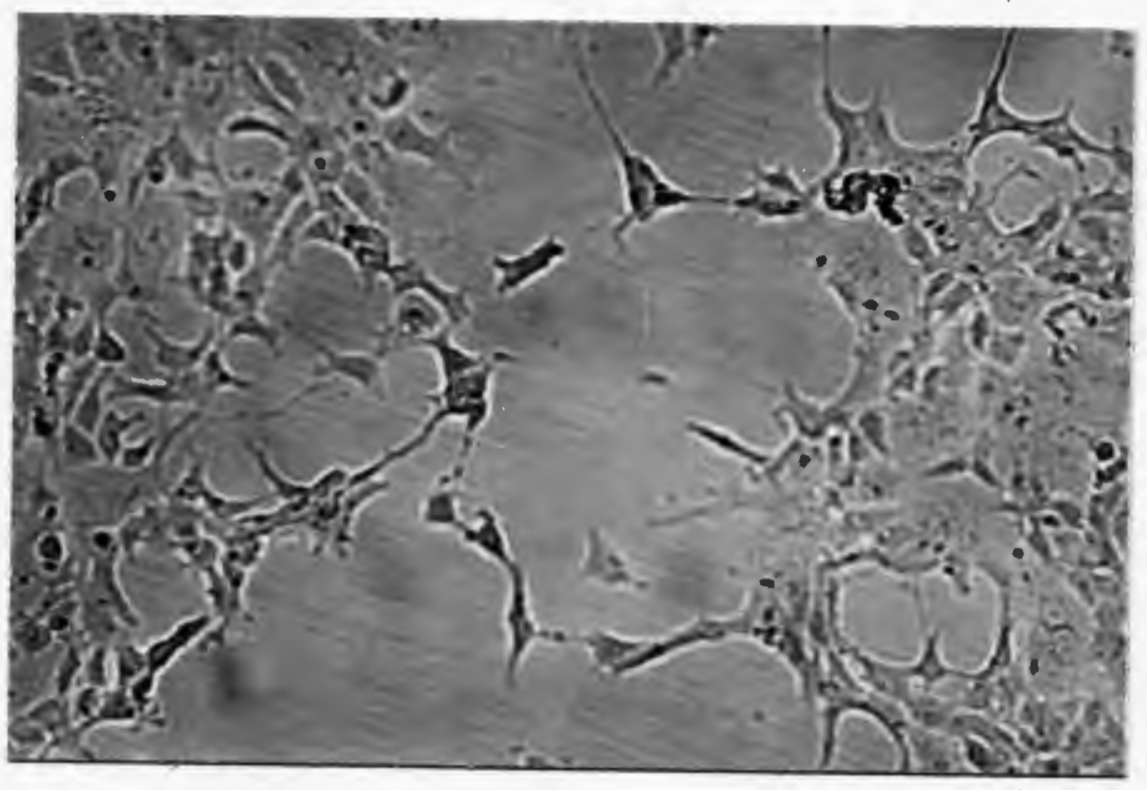

ㅇํㄴ

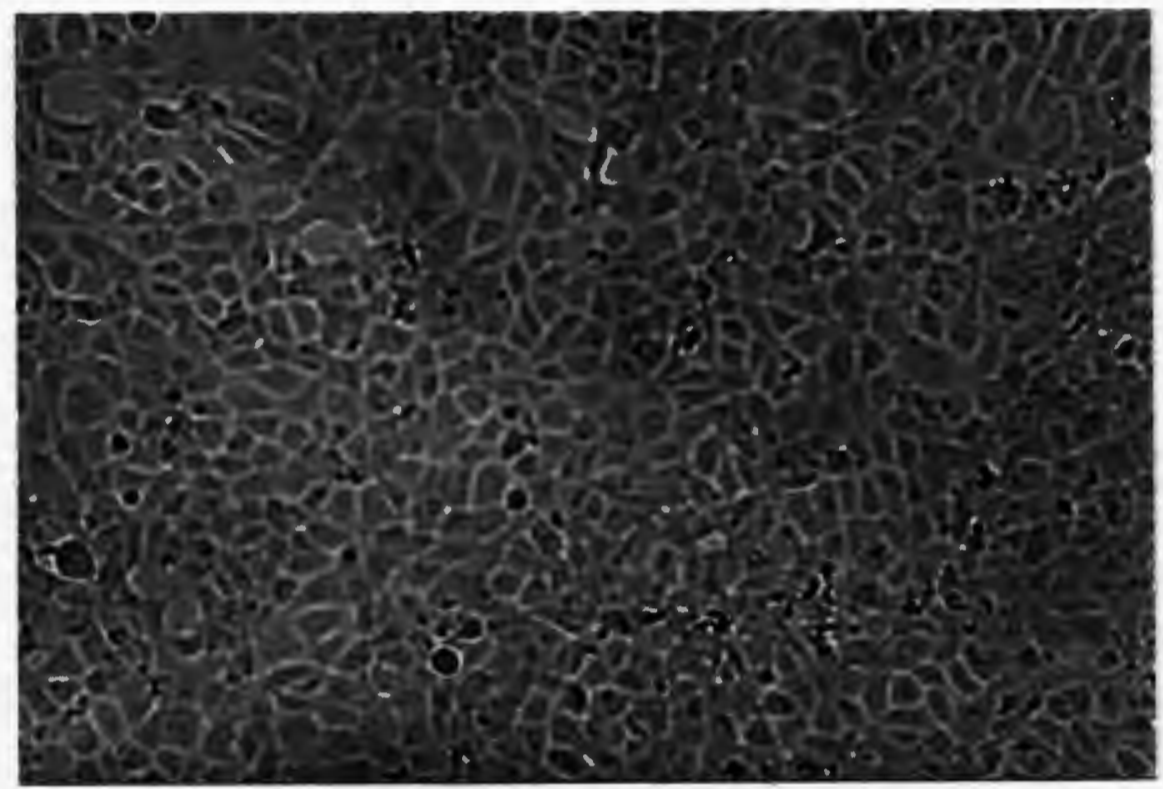

กำ 


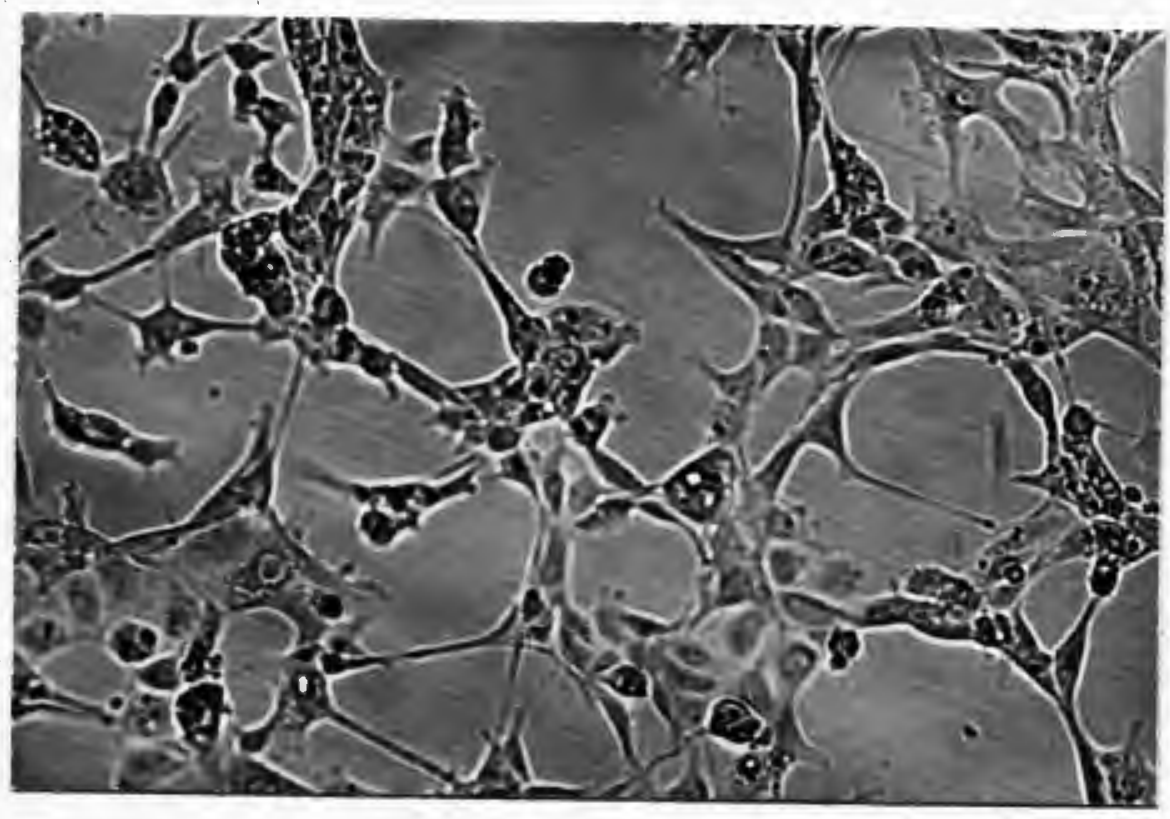

$\stackrel{0}{m}$

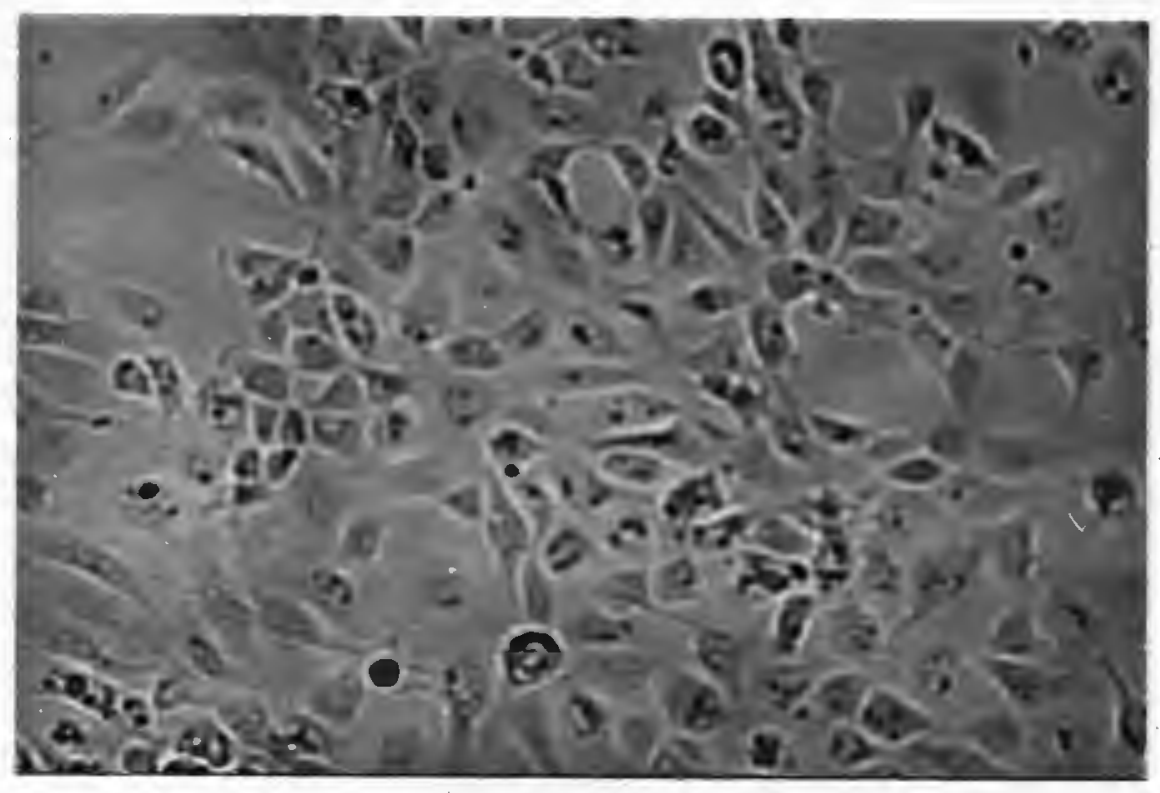

$\sqrt{\pi}$ 
Live virus was included in experimental systems in order to try to transform various tissue culture preparations. To determine if transformation occurred in cells infected with herpesviruses, 2 obvious changes in growth patterns were important: loss of contact inhibition whereby cell sheets became many layers thick rather than the usual regulated monolayer formation of non-malignant cells, and the ability to replicate continuously so that subcultures could be made indefinitely.

If CPE was not demonstrated in cultures inoculated with herpesviruses those cultures as well as uninfected controls were allowed to continue to grow. Fish cell lines designated STE-137 and CHSE-214 had been. spontaneously transformed earlier so that indefinite growth could not be used as a parameter to detect new alterations.

It is doubtful if normal fish cells were ever transformed in these experiments. Ten normal cultures could be divided as many as 10 times following infection; nor did cultures lose their ability to develop contact inhibition. Possibly the 2B cell cultures underwent a spontaneous type transformation similar to that which occurred in STE137 and CHSE-214.

Other experiments involving live viruses concerned whether or not HSV-1 or HSV-2 multiplied in fish cells. Cultures showing cytopathic effect were tested for virus multiplication after a given virus preparation had been 
passed 3 times in fish tissue cultures.

The results of these experiments showed that there was no significant difference in the number of pox formations observed on chlorioallantoic membranes of fertile eggs in the test system when compared with the number of lesions detected on control cultures. This was true for all the cultures tested, and with both viral types.

Use Of Viral DNA

When viral DNA was included as a transforming agent, no cytopathic effect was observed. When viral DNA was added to CHSE-214, STE-137, or $2 \mathrm{~B}$ ce11s cultures, these cells growing in culture did not show a loss of contact inhibition. Normal fish cells tested did not demonstrate a loss of contact inhibition nor the ability to replicate indefinitely.

U1 traviolet Light Inactivated Virus

Duff and Rapp (4) reported that ultraviolet light inactivated type 2 herpesvirus, when exposed for the proper time interval, increased the total growth of cells in culture over that of control systems. The time interval used was that interval found to be effective just prior to the time before ultraviolet light exposure completely inhibited the virus.

For HSV-1, 30 min completely inhibited the virus (no CPE was observed). Therefore $15,20,25,30$, and $35 \mathrm{~min}$ 
exposures were chosen in order to attempt to transform cultures. Since HSV-2 was inactivated with a $25 \mathrm{~min}$ exposure to ultraviolet light, $10,15,20,25$, and $30 \mathrm{~min}$ exposure intervals were used.

None of the times tested, nor the viruses treated had any visible effect on tissue cultures. Cultures STE137, CHSE-214, 2B, and normal cultures grew in a monolayer pattern only, and normal cells were unable to undergo 10 passage transfers. 


\section{DISCUSSION}

Experimental results showed that the only visible effect 2 types of human herpesviruses had on the 3 fish cultures studied was the ability to cause cell death in all fish culture systems tested. This finding was in agreement with Duff and Rapp (5) who said that HSV destroyed cells in vitro. Also these results were similar to studies done by Officer (15) and Nims (14) who demonstrated cytopathic effects due to VEE, EEE, and WEE when such viruses infected cultures prepared from fish cells.

Such results suggested the possibility that environmental hazards might be encountered due to the presence of HSV- 1 and HSV- 2 in the aquatic environment.

According to the 3 methods followed in this investigation no evidence for transformation of fish tissue cultures by 2 types of human herpesviruses was observed, even though the methods used were effective in promoting transformation in other virus-celi systems. Aaronson and Todaro (1) were able to transform human diploid cells using DNA isolated from the SV40 tumor virus. Fong and Hsuing (7) transformed hamster embryo cell cultures by infecting cultures with a guinea pig herpes-like virus when they allowed the virus to adsorb to cells for $2-4 \mathrm{hrs}$. Following adsorption each culture was subcultured. Other investigators 
$(3,4,5,16,18)$ used ultraviolet light-irradiated HSV to transform cells. Each method tested in this investigation was effective for other systems but these procedures did not yield convincing evidence that transformation occurred when 2 human herpesviruses were introduced into cells obtained from so-called "cold blooded animals". It may be possible that human herpesviruses do not pose a potential environmental hazard to the fish population and therefore no harm to man can be expected by this chain of events. If so, this is a fortunate observation since herpesvirus type 2 is associated with malignant conversions in human subjects.

Officer (15) and Nims (14) were able to propagate mammalian viruses in fish tissue cultures, but they were not able to transform fish cells with the mammalian viruses they tested.

This investigator attempted to follow the infectious processes of herpesviruses types 1 and 2 in fish tissue cultures by techniques involving the use of electron microscopy. However, all data were inconclusive; therefore that portion of the study was discontinued.

If it had been possible to transform fish tissue cultures with human strains of herpesviruses another piece of information implicating $\mathrm{HSV}-1$ and $\mathrm{HSV}-2$ as carcinogens would have been presented. Even though transformation under laboratory testing conditions would have been artificial, such data could have led to more information concerning virus- 
cell genome interactions which occur in an altered cell. Perhaps the information gained leaves us with an optimistic outlook since types 1 and 2 herpesviruses do not appear to affect such an important food chain for man as that offered by our fish population.

Another fortunate outcome of this study was that the investigator was able to establish the $2 \mathrm{~B}$ cell line in continuous culture so that it can be used as an important tool for fish virology studies by others in the future. 


\section{SUMMARY}

By investigations carried out in the experiments described, effects of HSV- 1 and HSV-2 on 3 different cultures (STE-137, CHSE-214, and tissue cultures prepared from rainbow trout ovaries) were observed. When both HSV-i and HSV2 infected the 3 types of fish cell cultures the result observed was cell death concomitant with marked cytopathic effect.

The ability of 2 strains of human herpesviruses (types 1 and 2) to serve as transforming agents in fish tissue culture systems proved to be negative for all 3 cultures tested. Live virus, viral DNA, and ultraviolet lightinactivated virus did not appear to transform cultures according to guidelines used to detect such events.

Throughout the course of this 3 year investigation, 1 of the normal fish cultures appeared to have undergone spontaneous transformation in vitro since it has been pos sible to transfer it for an indefinite time interval. This culture can be used in the future by other investigators in order to continue studies with fish viruses. 


\section{BI BL IOGRAPHY}

1. Aaronson, S. A. and G. J. Todaro. 1969. Human Diploid Cell Transformation by DNA Extracted From The Tumor Virus SV40. Science. 166: 390-391.

2. Darai, G. and K. Munk. 1973. Human Embryonic Lung Cells Abortively Infected with Herpes Virus Hominis Type 2 Show Some Properties of Cell Transformation. Nature (London) New Biol. 241:268-269.

3. Duff, R. and F. Rapp. 1971. Oncogenic Transformation of Hamster Cells after Exposure to Herpes Simplex Virus Type 2. Nature (London) New. Biol. 233:48-50.

4. Duff, R. and F. Rapp. 1971. Properties of Hamster Embryo Fibroblasts Transformed in vitro after Exposure to Ultraviolet-Irradiated Herpes Simplex Virus Type 2. J. Virol. 8: 469-477.

5. Duff, R. and F. Rapp. 1973. Oncogenic Transformation of Hamster Embryo Cells after Exposure to Inactivated Herpes Simplex Virus Type 1. J. yirol. 12:209-217.

6. Fisher, T. 1976. Personal Communication.

7. Fong, K. Y. C. and G. D. Hsiung. 1973. In vitro Transformation of Hamster Embryo Cells by a Guinea Pig Herpes-Like Virus. Proc. Soc. Exp. Biol. Med. 144(3):974-978.

8. Frenke1, N., B. Roizman, E. Cassai, and A. Nahmias. 1972. A DNA Fragment of Herpes Simplex 2 and its Transcription in Human Cervical Cancer Tissue. Proc. Nat1. Acad. Sci., 69:3784-3789.

9. Fryer, J., A. Yusha, K. Pilcher. 1965. The in vitro Cultivation of Tissue and Cells of Pacific Salmon and Steelhead Trout. Ann. N. Y. Acad. Sci. $126: 566-586$. 
10. Kaplan, A., Editor. 1973. The Herpesviruses. Academic Press, New York. 739 p.

11. Macnab, J. C. M. 1974. Transformation of Rat Embryo Cells by Temperature-Sensitive Mutants of Herpes Simplex Virus. J. Gen. Virol. 24 : $143-153$.

12. Munyon, W., E. Kraiselburd, D. Davis, and J. Mann. 1971. Transfer of Thymidine Kinase to Thymidine Kinaseless L Cells by Infection with UltravioletIrradiated Herpes Simplex Virus. J. Virol. 7: 813-820.

13. Naib, Z. M., A. J. Nahmias, W. E. Josey, and J. L. Kramer. 1969. Genital Herpetic Infection: Association with Cervical Dysplasia. Cancer. $23: 940-945$.

14. Nims, L., J. L. Fryer, K. S. Pilcher. 1970. Studies of Replication of Four Selected Viruses in Two Cell Lines Derived from Salmonid Fish. Proc. Soc. Exp. Biol. Med. 135:6-12.

15. Officer, J. E. 1964. Ability of a Fish Cell Line to Support the Growth of Mammalian Viruses. Proc. Soc. Exp. Biol. Med. 116:190-194.

16. Rapp, F. and R. Duff. 1973. Transformation of Hamster Embryo Fibroblasts by Herpes Simplex Viruses Type 1 and Type 2. Cancer Res. 33: 1527-1534.

17. Rapp, F. and R. Duff. 1974. Oncogenic Conversion of Normal Cells by Inactivated Herpes Simplex Viruses. Cancer. 34:1353-1362.

18. Rapp, F., and C. Reed. 1976. Experimental Evidence for the Oncogenic Potential of Herpes Simplex Virus. Cancer Res. 36:800-806.

19. Rawls, W. E., W. A. F. Tompkin, and J. L. Melnick. 1969. The Association of Herpesvirus Type 2 and Carcinoma of the Uterine Cervix. Am. J. Epidemiol. 89:547-554.

20. Sanders, J. and M. G. Soret. 1954. Cultivation of Animal Viruses in Embryonic Teleost Cells. Trans. New York Acad. Sci. $17(1): 19-25$. 